\title{
FIFTY DOLLARS OF FISH: A COMMENT ON R. v. VAN DER PEET
}

\author{
DAVID W. ELLIOTT ${ }^{*}$
}

In $R$ v. Van der Peet, ' the Supreme Court moved closer to providing what was lacking in its 1990 decision in Sparrow ${ }^{2}$ - a workable theory of the source, constitutional entrenchment, and content of aboriginal rights. This was a landmark decision. ${ }^{3}$ It provided a general explanation of the basis of aboriginal rights. It described the general purposes of s. 35(1) of the Constitution Act, 1982. It formulated a three-part test for identifying the content of aboriginal rights in specific situations. Between the theory and the practical test, though, something more may have been needed.

\section{BACKGROUND}

In September 1987, Dorothy Van der Peet, a Sto:lo Nation status Indian, sold ten sockeye salmon to a non-Indian for fifty dollars. The fish had been caught by other members of Van der Peet's band, under a valid Indian food licence. The question here was not whether Sto:lo had a traditional right to fish salmon in the Fraser River for food or ceremonial purposes. It was whether the traditional right included the sale of fish. Federal regulatory provisions prohibited all kinds of sale or trade of fish. ${ }^{5}$ When Van der Peet was charged with violating these provisions, ${ }^{6}$ she claimed what was

Associate Professor, Department of Law, Carleton University.

R. v. Van der Peet, [1996] 2 S.C.R. 507, aff'g [1993] 5 W.W.R. 459 (B.C.C.A.), (rev'g [1991] 3 C.N.L.R. 161 (B.C.S.C.), aff'g [1991] 3 C.N.L.R. 155 (B.C. Prov. Ct.)) [hereinafter Van der Peet]. Van der Peet was one of three British Columbia cases rendered on this day on aboriginal rights claims involving the sale or trade of fish. In R. v. N.T.C. Smokehouse Lid., [1996] 2 S.C.R. 672 [hereinafter N.T.C. Smokehouse], the Court ruled by a seven to two majority that a group's traditional exchange of fish was insufficient to satisfy the integral practices test, and concluded that there was no aboriginal right. In $R$. v. Gladstone, [1996] 2 S.C.R. 723 [hereinafter Gladstone], the Court held that although an aboriginal group's traditional trade in herring spawn did meet the requirements of the integral practices test, the case must be sent back to trial for further evidence on the issue of justification under s. 35(1) of the Constitution Act, 1982.

$2 \quad$ R. v. Sparrow, [1990] 1 S.C.R. 1075 at 1099 [hereinafter Sparrow]. See W.I.C. Binnie, "The Sparrow Doctrine: Beginning of the End or End of the Beginning?" (1990) 15 Queen's L.J. 217; D.W. Elliott, "In the Wake of Sparrow: A New Department of Fisheries?" (1991) 40 U.N.B.L.J. 23.

3 An early indication of Van der Peet's significance is the fact that by October 1996, the Supreme Court had already applied its approach in five other decisions: $R$. v. Pamajewon, [1996] 2 S.C.R. 821; N.T.C. Smokehouse Lid., supra note 1; Gladstone, supra note 1; R. v. Adams, [1996] 3 S.C.R. 101 [hereinafter Adams]; R. v. Côté, [1996] 3 S.C.R. 139 [hereinafter Côté]. Schedule B to the Canada Act 1982 (U.K.), 1982, c. 11.

3 Section 27(5) of the British Columbia Fishery (General) Regulations, SOR/84-248 (hereinafter B.C. Fishery Regulations]. Section 27(5) stipulates that "[n]o person shall sell, barter or offer to sell or barter any fish caught under the authority of an Indian food fish licence."

6 Van der Peet was charged under S. 61(1) of the Fisheries Act, R.S.C. 1970, c. F-14, with selling fish caught under the authority of an Indian food fish licence, contrary to s. 27(5) of the B.C. Fishery Regulations, ibid. 
described as an aboriginal right to sell, barter or trade salmon. She argued that this right prevailed over the regulations by virtue of s. 35(1) of the Constitution Act, 1982.

Van der Peet's legal claim was part of a larger drama. Land and resources have special significance to aboriginal peoples, both culturally and materially. ${ }^{7}$ Trapped near the bottom of the economic ladder, many first peoples are claiming aboriginal rights to natural resources, for commercial as well as food purposes. ${ }^{8}$ On the other hand, natural resources like fish are declining amidst a storm of regulatory controversy and conflicting needs. In British Columbia, for example, the salmon fishing industry has been plagued by international quota disputes, habitat degradation, complaints of government mismanagement, federal-provincial bickering, high unemployment, and declining fish stocks. ${ }^{9}$ Moreover, some commentators claim a still wider reach for judicially-guaranteed aboriginal rights, raising questions about the role of courts and the allocation of governmental authority. ${ }^{10}$ Although the analysis here focuses on the legal and conceptual implications of Van der Peet, these larger issues are not far below the surface.

7 See testimony of aboriginal witnesses, reported in Royal Commission on Aboriginal Peoples, Report of the Royal Commission on Aboriginal Peoples (Ottawa: Minister of Supply and Services, 1996), vol. 2, c. 4, ss. 3.1 and 3.2 [hereinafter Royal Commission Final Report]. See also J. Cruikshank, Through the Eyes of Strangers: A Preliminary Survey of Land Use History in the Yukon During the Late Nineteenth Century (Whitehorse: Govt. of Yukon, 1974); P. Tennant, Aboriginal Peoples and Politics: The Indian Land Question in British Columbia, 1849-1989 (Vancouver: U.B.C. Press, 1990); O.P. Dickason, Canada's First Nations: A History of Founding Peoples from Earliest Times (Toronto: McClelland \& Stewart, 1992), c. 1-4; and D. Newell, Tangled Webs of History: Indians and the Law in Canada's Pacific Coast Fisheries (Toronto: University of Toronto Press, 1993), c. 2.

- A right to sell fish or fish commercially was claimed not only in Van der Peet but in N.T.C. Smokehouse, supra note 1 and Gladstone, supra note 1 . See also S. Gilby, "The Aboriginal Right to a Commercial Fishery" (1995) 4 Dal. J. Leg. Studies 231. Before 1992, aboriginal people participated in the commercial fishery on the same general basis as non-aboriginals. In 1992, the Department of Fisheries began the Aboriginal Fisheries Strategy, a program which allocated to signatory Indian bands in British Columbia a separate part of the salmon harvest for commercial purposes. For two contrasting assessments of the AFS, see M.H. Smith, Our Home or Native Land? (Victoria: Crown Western, 1995), c. 9; and Newell, ibid at 77-78. Unlike the AFS or other government policies, an aboriginal right to fish commercially would be guaranteed constitutionally. For a sample of the problems, see D.S. Boyer, "The Untamed Fraser: British Columbia Lifeline" (July 1986) 170 National Geographic 44; J.F. Roos, Restoring Fraser River Salmon: A History of the International Pacific Salmon Fisheries Commission, 1937-1985 (Vancouver: Pacific Salmon Fisheries Commission, 1991); G. Meggs, Salmon and the Decline of the B.C. Fishery (Vancouver: Douglas \& McIntyre, 1992); Newell, ibid;; J. Allain and J.-D. Fréchette, The Aboriginal Fisheries and the Sparrow Decision (Ottawa: Supply and Services Canada, 1994); Fraser River Sockeye Public Review Board, Fraser River Sockeye 1994: Problems and Discrepancies (Ottawa: Public Works and Government Services Canada, 1995); T.L. Slaney, "Status of Anadromous Salmon and Trout in British Columbia and Yukon" (1996) 21:10 Fisheries 20; Pacific Salmon Commission, 1995/96 Eleventh Annual Report (Vancouver: P.S.C., 1996), chart at 53, showing catch declines in most of the southern regions of British Columbia. 
Van der Peet's conviction was upheld by most of the lower British Columbia courts $^{11}$ and by a majority of seven to two in the Supreme Court of Canada. ${ }^{12}$ Speaking for the majority of the Supreme Court, Lamer C.J.C. built on the version of the distinctive practices test favoured by the majority of the British Columbia Court of Appeal. ${ }^{13}$ However, he attempted to put it into the context of a general theory of both aboriginal rights and the purpose of s. 35(1) of the Constitution Act, 1982.

Lamer C.J.C. started with general interpretation issues. He said the fiduciary relationship between the Crown and aboriginal peoples requires courts to give a liberal interpretation to provisions that protect these peoples, and to construe ambiguities in their favour. He noted that the meaning of s. 35(1) depends on the meaning of aboriginal rights. Then he said that the basis of aboriginal rights is the fact that when the Europeans came to North America, aboriginal peoples were already occupying the land and participating in distinctive cultures. ${ }^{14} \mathrm{He}$ said the purpose of s. $35(1)$ is to reconcile this prior occupation of land by distinctive aboriginal societies with the Crown's assertion of sovereignty. ${ }^{15}$

Lamer C.J.C. went on to formulate a three-part "distinctive practices" test ${ }^{16}$ for identifying specific aboriginal rights. He said a court should first characterize precisely the aboriginal claim, then determine if the activity in question was part of a pre-

Van der Peet lost in the British Columbia Provincial Court, Van der Peet (B.C. Prov. Ct.), supra note 1; succeeded in the British Columbia Supreme Court, Van der Peet (B.C.S.C.), supra note 1; and then lost again in a majority decision of the British Columbia Court of Appeal, Van der Peet (B.C.C.A.), supra note 1. In the Court of Appeal the majority (Macfarlane J.A. for himself and Taggart J.A.; Wallace J.A. concurring separately) applied the "distinctive practices" test they had formulated in Delgamuukw v. British Columbia, [1993] 5 W.W.R. 97 [hereinafter Delgamuukw]; see Van der Peet (B.C.C.A.), supra note 1 at 467-69 (paras. 18-28), 482-83 (paras. 91-93), applying Delgamuukw at 124-25 (paras. 40-47) (Wallace J.A. concurring at 183 (para. 303)). They concluded that the Sto:lo's traditional trade in salmon was insufficient to be integral to their distinctive culture. Lambert and Hutcheon JJ.A. dissented. While the majority of the Court of Appeal related aboriginal rights to occupancy and use of land, and by extension to resources such as water (Macfarlane and Taggart JJ.A. at 468 (para. 27) and Wallace J.A. at 487 (para. 110)), Lambert J.A. at 493 (para. 131) said "[a]boriginal rights have their origin in the customs, traditions and practices of the [relevant aboriginal people]." He said the customs, traditions and practices "which formed an integral part of the distinctive culture of the aboriginal people in question [at the relevant time]" gave rise to aboriginal rights (ibid. at 493 (para. 131)). From here Lambert J.A. went on to articulate an aboriginal right to a moderate livelihood from traditionallyused resources (ibid. at 494-504 (paras. 131-66)). Applying this approach, Lambert J.A. said that because the traditional use of salmon was integral to Sto:lo culture, the Sto:lo should be entitled to catch enough in modern times to provide themselves with a "moderate livelihood" (ibid. at 499500 (para. 150)). Hutcheon J.A. dissented on other grounds (ibid. at 513 (para. 208)). Van der Peet (S.C.C.), supra note 1.

Van der Peet (B.C.C.A.), supra note 1.

Van der Peet (S.C.C.), supra note 1 at 538-39 (para. 30). This proposition is at the heart of the Van der Peet decision's general "land and societies" approach to the source of aboriginal rights. For the land component, see Part II below; for the distinctive societies component, see Part III below. Ibid. at 539 (para. 31).

16 Or, as Lamer C.J.C. called it, the "integral to a distinctive culture" test (ibid. at 553, 564 (paras. $55,56,80$ )). See also $549-57$ (paras. $46,48,51-54,55,57-59$, and $60-65$ ). 
European contact practice that was integral to the distinctive culture in question, and then decide if there is sufficient continuity between the modern activity and the traditional practice. If the test identifies an aboriginal right, the court can apply the extinguishment, infringement, and justification tests laid down in Sparrow ${ }^{17}$ to determine if the right is protected by s. 35(1) of the Constitution Act, 1982. The aim, said Lamer C.J.C., is to determine if a practice was a "defining feature" of the aboriginal culture in question. ${ }^{18} \mathrm{He}$ said courts should be sensitive both to the aboriginal perspective and to the need to approach this perspective "in terms which are cognizable to the non-aboriginal legal system." 19

For the first stage, Lamer C.J.C. stressed that the characterization should be specific. ${ }^{20}$ For the second stage of the test, he said "integral" means "central and significant, ${ }^{121}$ and means independent, not incidental significance. ${ }^{22}$ The term "distinctive"23 excludes features common to all societies, ${ }^{24}$ but does not require uniqueness. ${ }^{25}$ The focus should be on the particular aboriginal community in question. ${ }^{26}$ Both for evidentiary requirements and continuity, the courts should not apply standards that are too rigid or demanding. ${ }^{27}$

Applying the first part of the test, Lamer C.J.C. noted that Van der Peet had only sold ten salmon, that there was no evidence of similar sales "on other occasions or on a regular basis,"128 and that the regulations prohibited all sale or trade of fish caught under an Indian food fish licence. ${ }^{29}$ Thus, he said, the relevant question was not whether Van der Peet had an aboriginal right to sell salmon commercially, but whether

Supra note 2.

Van der Peet (S.C.C.), supra note 1 at 554 (para. 59).

Ibid. at 551 (para. 49).

Ibid. at 551 (para. 51). Lamer C.J.C. said characterization should focus on the significance of actual practices to the distinctive culture of the claimant group, not on whether a general area of activity is significant for a broad ultimate goal such as livelihood (ibid. at 564 (para. 79)).

Ibid. at 553 (para. 55). He said the practice must be such that without the practice the culture would be fundamentally altered (ibid. at 554 (para. 59)).

Ibid. at 560 (para. 70 ).

Lamer C.J.C. referred (ibid. at 548-49 (para. 45)) to the Court's later statement in Sparrow that "for the Musqueam, the salmon fishery has always constituted an integral part of their distinctive culture" (Sparrow, supra note 2 at 1099 [emphasis added by Lamer C.J.C.]). The British Columbia Court of Appeal adapted this statement in their own different sets of reasons in Van der Peet (see discussion supra note 11). The term was also used in Calder v. British Columbia (A.G.), [1973] S.C.R. 313 [hereinafter Calder] where Hall J. observed that the Nisga'a "are and were from time immemorial a distinctive cultural entity with concepts of ownership indigenous to their culture and capable of articulation under the common law" (at 375). In Calder and Sparrow, the term appeared to be one means of describing aboriginal rights; in Van der Peet (S.C.C.), ibid, it became a required element for identifying aboriginal rights. Outside aboriginal law the term "distinctiven is often associated with trademark law, where it refers to features that distinguish or identify (see, for example, Canada (Registrar of Trade Marks) v. G.A. Hardie \& Co., [1949] S.C.R. 483).

Such as "eating to survive" (Van der Peet (S.C.C.), ibid. at 553 (para. 56)).

Ibid. at 560-61 (para. 71).

Jbid. at 559 (para. 69).

Ibid. at 556-57 (paras. 64-65) (continuity) and at 558-59 (para. 68) (evidence).

Ibid. at 563 (para. 77).

Ibid. at 563 (para. 78). 
she could establish an aboriginal right to exchange fish for money or other goods i.e., other than in "the commercial marketplace." 30

On the second part of the test, Lamer C.J.C. agreed with the trial judge that while the Sto:lo had traded traditionally in salmon, they did not do so on a large scale and in an organized way. The trade was only occasional, and was incidental to fishing for food and ceremonial purposes. Hence the exchange of fish for money or other goods was not an integral part of the Sto:lo's distinctive traditional culture before contact with the Europeans. Finally, Lamer C.J.C. agreed that the Sto:lo's trade with Hudson's Bay Company officials was qualitatively different from the traditional practices, so that there was no continuity here. As a result, Van der Peet could not claim an aboriginal right today.

L'Heureux-Dube' and McLachlin JJ. dissented in separate judgments. L'HeureuxDubé J. agreed with the majority's approach to general interpretation principles ${ }^{31}$ and to the basis of aboriginal rights. ${ }^{32}$ Although she also supported a distinctive practices test ${ }^{33}$ she would have applied it more broadly than the majority. ${ }^{34}$ She found an aboriginal right, but would have sent the case back to trial because of insufficient evidence on the issues of extinguishment, infringement, and justification. McLachlin $\mathrm{J}$. would have focused the distinctive practices test on the question of a traditional right to derive sustenance from the land or natural resource in question. ${ }^{35}$ She would have recognized a current right to secure a "moderate livelihood" from the land or resource, in a modern manner, and subject to conservation and safety constraints. ${ }^{36}$ She said

Ibid. at 569 (para. 88).

Ibid. at 588 (para. 141). However, L'Heureux-Dube J. did not agree that consideration of the aboriginal perspective should be balanced by a concem to incorporate this perspective into the common law (ibid. at 589 (para. 145)).

32 L'Heureux-Dube J. saw aboriginal rights as "arising out of the historic occupation and use of native ancestral lands" and as "part of a distinctive aboriginal culture" (ibid. at 579 (para. 116)). However, she suggested that these rights could include not only aboriginal title and rights to hunt, fish or trap, and accompanying rights, but also "other matters, not related to land, that form part of a distinctive aboriginal culture" (ibid. and see 581 (para. 121)). It is difficult to understand how a matter can arise out of occupation and use of land and not relate to land.

Ibid. at 589-95 (paras. 147-62).

L'Heureux-Dube J. said courts must not limit their search to individual practices that are unique to aboriginal cultures (ibid. at 591-92 (paras. 150-54), and see 602-603 (para. 180)), and that courts should not limit themselves to pre-contact times when looking for distinctive traditional practices. She said a practice should be integral to the distinctive culture "for a substantial continuous period of time" (ibid. at 601 (para. 175) [emphasis added by L'Heureux-Dubé J.]) - either before or after European contact or sovereignty - and that a period of twenty to fifty years would qualify for these purposes (ibid. at 602 (para. 178)).

McLachlin J. said the distinctive practices test was insufficient by itself to provide a satisfactory means of identifying aboriginal rights (ibid. at 637-38 (para. 255)). She said the test should be qualified by inquiring to see "what sort of practices have been identified as aboriginal rights in the past" (ibid. at 641 (para. 261)). From this inquiry, McLachlin J. concluded that the right to live off the land and its resources had been recognized historically as a fundamental aboriginal right (ibid. at 646, 648 (paras. 272, 275)). See further, Part VIl infra.

Ibid. at 649-50 (paras. 279-80), and Part VII infra. 
Van der Peet could claim such a right. ${ }^{37}$ Since this right had not been extinguished, and had been unjustifiably infringed, the conviction should be set aside.

\section{BASIS OF ABORIGINAL RIGHTS: LAND}

Because it was unclear if fishing for non-food or non-ceremonial purposes could in fact be an aboriginal right, the Court needed a test for identifying aboriginal rights. Since it would be logical to relate such a test to the basic features of aboriginal rights, the Court also needed a general theory of aboriginal rights. Before Van der Peet, the case law had moved from grounding aboriginal rights in the Royal Proclamation of 1763 , basing them in prior occupancy and use of land. ${ }^{38}$ On the other hand, the Supreme Court had not yet articulated a comprehensive general theory about the basis of aboriginal rights. ${ }^{39}$

In his majority judgment in Van der Peet, Lamer C.J.C. suggested that the essence of aboriginal rights is the aboriginal peoples' prior occupation of land in distinctive societies. He said the basis of aboriginal rights is the fact that

when Europeans arrived in North America, aboriginal peoples were already here, living in communities on the land, and participating in distinctive cultures, as they had done for centuries. It is this fact, and this fact above all others, which separates aboriginal peoples from all other minority groups in Canadian society and which mandates their special legal, and now constitutional, status. ${ }^{40}$

Aboriginal rights, said Lamer C.J.C., are "based in the prior occupation of North America by distinctive aboriginal societies. ${ }^{141}$ Land, then, was clearly one of the two key components of the foundation of aboriginal rights. Lamer C.J.C. included the prior aboriginal relationship to land as a vital part of what sets aboriginal peoples apart from all other minorities and justifies the special legal status of aboriginal rights. ${ }^{42}$ At another point Lamer C.J.C. referred to "the existence of distinctive aboriginal communities occupying 'the land as their forefathers had done for centuries," 43 and to a "pre-existing occupation and use of the land." ${ }^{44} \mathrm{He}$ said that the purpose of $\mathrm{s}$. $35(1)$ is to reconcile this fact of prior occupation of land by distinctive aboriginal

Ibid. at 652 (paras. 283-84).

Calder, supra note 23 was instrumental in suggesting that Indian title claims do not depend exclusively on the Royal Proclamation, but derive as well from common law recognition of aboriginal occupancy and use of land prior to the arrival of the Europeans.

Although the two leading judgments in Calder, ibid., strongly supported occupancy and use, they did not address the questions of content and basic features comprehensively; the post-Calder decisions did not add much more about the content of aboriginal rights; and Sparrow (supra note 2 at 1094) was directed more to status than content.

Van der Peet (S.C.C.), supra note 1 at 538 (para. 30) [emphasis in original].

Ibid. at 540-41 (para. 35), suggesting that this view also has support in early American case law. Ibid. at 538-39 (para. 30).

Ibid. at 540 (para. 33).

Ibid. at 544 (para. 37), saying that this feature and possession of the soil from time immemorial are as relevant to the identification of the interests that s. 35(1) was intended to protect, as it was in the early American case of Worcester v. Georgia, 31 U.S. (6 Pet.) 515 (1832) [hereinafter Worcester]. 
societies with the Crown's assertion of sovereignty. ${ }^{45}$ McLachlin J. put a similar emphasis on occupation of lands in her dissenting judgment. ${ }^{46}$

This emphasis on land contrasts with a number of recent calls for a broader approach. Some commentaries ${ }^{47}$ and judgments ${ }^{48}$ claim that aboriginal rights extend far beyond land and land-related interests to encompass aboriginal law and custom in general. In support of this claim, they can argue that it provides a more comprehensive refection of traditional life than do claims based on land. For support, they tend to rely on comments in decisions such as Connolly v. Woolrich, ${ }^{49}$ Worcester v. Georgia, ${ }^{50}$ and $R$. v. Sioui. ${ }^{\text {st }}$

Ibid. at 539 (para. 31).

McLachlin J. referred generally to "two fundamental principles" - "that the Crown took subject to existing aboriginal interests in the lands they traditionally occupied and their adjacent waters [and that the interests were to be removed only by treaty with compensation] (ibid. at 648 (para. 275) [emphasis added]). She said an aboriginal right is established "[i]n so far as an aboriginal people under internal law or custom had used the land and its waters in the past" (at 645 (para. 269)). L'Heureux-Dube J., dissenting, also saw land as important to the basis of aboriginal rights although she did not appear to regard it as vital to the content of aboriginal rights (see supra note 32).

47 For example, M. Walters, "British Imperial Constitutional Law and Aboriginal Rights: A Comment on Delgamuukw v. British Columbia" (1992) 17 Queen's L.J. 350, articulating a general theory about aboriginal rights which extends beyond land and resources connected with land. (Although a compelling case can be made for "some sort of intermediary category between conquest and settlement," as suggested in note 85 of the article, there is still a question as to that category's general content. In D.W. Elliott, "Aboriginal Title" in B.W. Morse, ed., Aboriginal Peoples and the Law (Ottawa: Carleton University Press, 1985) 48, the comment at 60 about assimilating conquest and settlement referred not to aboriginal laws but to the survival of "antecedent rights" (ibid. note 85). See also discussion paper of Royal Commission on Aboriginal Peoples, Partners in Confederation: Aboriginal Peoples, Self-Government, and the Constitution (Ottawa: Minister of Supply and Services, 1993) and Royal Commission Final Report, supra note 7 at 189.

In Delgamuukw, supra note 11 at 290-92 (paras. 718-28); Van der Peet (B.C.C.A.), supra note 1 at 470 (para. 37); and their 25 June 1993 companion decisions in the British Columbia Court of Appeal, Lambert J.A., dissenting, supported an identification test for aboriginal rights that was free of any necessary tie to land. Lambert J.A. also spoke for a three-judge Court of Appeal panel which held that native customary adoption can be the subject of aboriginal rights (Casimel $\mathbf{v}$. Insurance Corp. of British Columbia (1993), 106 D.L.R. (4th) 720 at 727-28 (B.C.C.A.)). See also Manychief v. Poffenroth (1994), 25 Alta. L.R. (3d) 393 (Alta. Q.B.).

(1867), 17 R.J.R.Q. 75, 11 L.C. Jur. 197, 1 C.N.L.C. 70 (Que. Sup. Ct., cited to R.J.R.Q.) [hereinafter Connolly]. In Connolly, Monk J. recognized the validity of an Indian customary marriage in the Athabaska Territory in 1803. He said "the territorial rights, political organization, such as it was, or the laws and usages of the Indian tribes" continued in full force, even assuming that European law applied at trading posts in the region in question (at 84). The Royal Commission Final Report used Monk J.'s decision to help support the proposition that aboriginal rights are based generally on "unwritten sources such as long-standing custom and practice" (supra note 7 at 189). The Royal Commission Final Report concluded that aboriginal rights that continue past European sovereignty include "special linguistic, cultural, and religious rights" and other rights such as "rights of self-government" (ibid.).

Supra note 44 at $515,540,547,552,557,558$.

[1990] I S.C.R. 1025 at 1055. In Worcester, ibid., and Sioui, the Supreme Court of the United States and the Supreme Court of Canada, respectively, commented about the British policy of treating Indians as nations, with internal autonomy. 
For their part, supporters of a more land-based approach to aboriginal rights can stress that original occupation of North America, ${ }^{52}$ with a close and distinctive relationship to the land, ${ }^{53}$ is a claim no other group can make. Supporters of this approach might note that comments in decisions such as Connolly, Worcester, and Sioui referred to situations in which European sovereignty was only imperfectly established, ${ }^{54}$ and may be less applicable to later times. ${ }^{55}$ They might argue that traditional laws and customs may be harder to prove than practices relating to occupancy or use. ${ }^{56}$ As well, they can claim that the concept of prior aboriginal

There is strong evidence of human occupation of North America from at least 11,500 B.C. and perhaps earlier. See, for example, B.M. Fagan, The Great Journey: The Peopling of Ancient America (London: Thames and Hudson, 1987), c. 5; R. McGhee, "Prehistory" The Canadian Encyclopedia, 2d ed., vol. 3 (Edmonton: Hurtig, 1988) at 1737; J. Cinq-Mars, "La Place des Grottes du Poisson-Bleu dans la Préhistoire Béringienne" (1990) 1 Revista Arqueologia Americana 9 at 26-27; S.J. Fiedel, Prehistory of the Americas, 2d ed. (New York: Cambridge U. Press, 1992) at 56-59; Dickason, supra note 7 at 25; E.J. Dixon, Quest for the Origins of the First Americans (Albuquerque: University of New Mexico Press, 1993). Artifacts at Monte Verde, Chile, have been dated at about 12,500 B.P. (T.D. Dillehay \& M.B. Collins, "Early Cultural Evidence from Monte Verde in Chile" (1988) 332 Nature 150; and J.N. Wilford, "We've been here longer than we thought" Globe and Mail (22 March 1997) D5; updating the findings at Monte Verde). If migration to South America passed through North America, this suggests a date at least as old for North America.

For the special significance of land and related resources to aboriginal peoples, see supra note 7. Arguably, European presence, government and sovereignty in the Athabaska Territory in 1803 was minimal. Within Rupert's Land, the "governmental" powers of the Hudson's Bay Company applied only to its employees. The Athabaska area lay beyond even the territory of the Hudson's Bay Company. There was no true settlement in the Athabaska area - just a handful of forts and some early fur trade activity. Hence Monk J.'s decision does not necessarily support the theory that all forms of pre-existing customs and laws, including self-government laws, survived the more complete changes of sovereignty that occurred later and elsewhere. Although the decision was upheld by the majority of the Quebec Court of Appeal (in (1869), 17 R.J.R.Q. 266) their language was more restrained, and was inconsistent with any broad claim to common law self-government rights (ibid. at 333-34). They too stressed the limited nature of the European presence in the region in 1803 (Badgley J., ibid. at 332-33; Mackay J., ibid. at 346, 352; and Loranger J. (dissenting on another point), ibid. at 276); Duval J. concurred with his colleagues (ibid.). Before quoting the comments in Worcester, Lamer C.J.C. noted that they referred to "British policy towards the Indians in the mid-eighteenth century" (Sioui, supra note 51 at 1053). Lamer C.J.C.'s own comments were also made in the context of eighteenth-century Indian-European relations. However, the Royal Commission discussion paper considered both comments to be "persuasive reasons for concluding that under the common law doctrine of Aboriginal rights, Aboriginal peoples have an inherent right to govern themselves within Canada" (supra note 47 at 21). The Royal Commission Final Report cited the same comments and came to a similar conclusion (supra note 7 at 192).

In most of North America, European sovereignty was imposed gradually, rather than overnight: see the comments by L'Heureux-Dube J. in Van der Peet (S.C.C.), supra note 1 at 597 (para. 167) about the difficulty of establishing an exact date for British sovereignty. In Baker Lake v. Minister of I.A.N.D., [1980] 1 F.C. 518 at 562 (F.C.T.D.), Mahoney J. suggested that English sovereignty had been established in the Baker Lake area "probably no earlier than 1610 and certainly no later than May 2, 1670." Even in regard to the more standard "conquest" situation after the fall of New France, the Supreme Court has referred to the "transition" to British sovereignty (Côté, supra note 3 at 151, 162 (paras. 4, 42); Adams, supra note 3 at 108, 120 (paras. 4, 32)). Early situations might bear little resemblance to those later on. 
occupancy has strong support both in historic government instruments ${ }^{57}$ and in case law in the United States, ${ }^{58}$ former British colonies, ${ }^{59}$ Australia, $^{60}$ and Canada. ${ }^{61}$

Rights associated with the occupation and use of land and adjoining resources were the main focus of protection in the Indian provisions of the Royal Proclamation of 1763. After an initial contact period, land rights became an increasingly central feature in Indian treaties. See Lamer C.J.C. in Van der Peet (S.C.C.), supra note 1 at $541-43$ (para. 36), referring to Johnson v. M'Intosh, 21 U.S. (8 Wheat.) 543 at 574 (1823). Marshall C.J. referred throughout to the Indian right "of possession" (ibid. at 574, 580, 582, 583, 584, 588, 590, 591, 603); and of "occupancy" (ibid. at $574,583,588$ ). This right was considered to have survived sovereignty at common law (with additional assistance from the Royal Proclamation of 1763), and to be capable of supporting a common law action in ejectment (ibid. at 592). Although Marshall C.J.'s later decision in Worcester, supra note 44 affirmed a right of self-government as well as occupancy-based aboriginal rights, the wider right appeared to be based heavily on its specific acknowledgement in early American peace treaties and federal legislation. In Worcester itself, the Supreme Court held that Georgia laws which interfered with the Cherokee were invalid on the ground that the state laws were "repugnant to the Constitution, laws, and treaties of the United States" (ibid. at 562). On Worcester, see also supra notes 50 and 51. See also County of Oneida v. Oneida Indian Nation, 470 U.S. 226 (1985) at 233-34: "By the time of the Revolutionary War, several well-defined principles had been established governing the nature of a tribe's interest in its property and how those interests could be conveyed. It was accepted that Indian nations held 'aboriginal title' to lands they had inhabited from time immemorial." "[This court has recognized at least implicitly that] Indians have a federal common-law right of action for an accounting of 'all rents, issues and profits' against trespassers on their land" (ibid. at 235-36).

Most later colonial decisions support the survival of antecedent aboriginal rights associated with land: see Wi Parata v. Bishop of Wellington (1877), [1878] 3 N.Z. (Jur.) N.S. 72 at 77 (N.Z.S.C.): "native proprietary rights" (although there is also a reference to the "old laws of the country," the emphasis is on proprietary rights); Cook v. Sprigg, [1899] A.C. 572 at 578 (P.C.): "private property"; Nireaha Tamaki v. Baker (1900), [1901] A.C. 561 at 578 (P.C.): "possession and occupation of ... lands ... under a native title"; A.G. (Southern Nigeria) v. Holt, [1915] A.C. 599 at 609 (P.C.); Amodu Tijani v. Secretary, Southern Nigeria, [1921] 2 A.C. 399 at 407, 409-10 (P.C.); Bakare Ajakaiye v. Lieutenant-Governor, Southern Provinces, [1929] A.C. 679 at 682 (P.C.); Adeyinka Oyekan v. Musendiku Adele, [1957] 2 All E.R. 785 at 788 (P.C.). Mabo v. Queensland [No. 2] (1992) 175 C.L.R. 1 at 57 (High Court of Australia): "[t]he preferable rule equates the indigenous inhabitants of a settled colony with the inhabitants of a conquered colony in respect of their rights and interests in land" (the remainder of the quotation refers to Re Southern Rhodesia, [1919] A.C. 211 at 233, 235 (P.C.), which spoke of rights in or equivalent to property as being the kind of private rights that could survive conquest).

The "Indian title" referred to in St. Catherine's Milling and Lumber Co. v. R. (1888), 14 A.C. 46 at 55 (P.C.) [hereinafter St. Catherine's Milling], above, was a land-based title ascribed to the Royal Proclamation of 1763. In Calder, supra note 23 at 375, Judson J. said that "when the settlers came, the Indians were there, organized in societies and occupying the land as their forefathers had done for centuries. This is what Indian title means...." Hall J. said that "[t]he issue here is whether any right or title the Indians possess as occupants of the land from time immemorial has been extinguished" (ibid. at 352 [emphasis added]). In $R$ v. Guerin, [1984] 2 S.C.R. 335 at 376, Dickson C.J.C. summarized Calder as holding that aboriginal title is "a legal right derived from the Indians' historic occupation and possession of their tribal lands." In Sparrow, supra note 2 at 1094, the Court noted that "the Musqueam have lived in the area as an organized society long before the coming of European settlers, and ... the taking of salmon was an integral part of their lives and remains so to this day." See also Delgamuukw, supra note 11 at 128-29 (para. 65) and 206 (paras. 396-99). 


\section{BASIS OF ABORIGINAL RIGHTS: DISTINCTIVE SOCIETIES}

The other main element of the majority's description of the basis of aboriginal rights was prior participation in distinctive aboriginal societies. Although the majority did not elaborate on the role of the "distinctive" requirement in this context, ${ }^{62}$ the phrase as a whole may have been intended to reflect at least two important features of the prior aboriginal presence. ${ }^{63}$ First, the phrase clarifies that the prior occupancy and use on which aboriginal rights are based was not fleeting and random but was well established and socially organized. Second, it underlines the fact that the prior occupancy was not individual but communal in nature.

After speaking of prior occupancy by distinctive societies, Lamer C.J.C. said this is what distinguishes aboriginal peoples from all other minority groups in Canada and justifies the special legal status of aboriginal rights. ${ }^{64}$ In other words, presumably, it is the prior occupancy of land by aboriginal societies that is at the root of what is distinctive about aboriginal rights. As will be seen, though, this interpretation appears to contrast with the meaning Lamer C.J.C. gave "distinctive" later, in the context of identifying aboriginal rights. ${ }^{65}$

This general tie between aboriginal rights and land did not require that aboriginal rights be synonymous with aboriginal title. As Lamer C.J.C. said, "[a]boriginal title is the aspect of aboriginal rights related specifically to aboriginal claims to land." Nevertheless, "[b]oth aboriginal title and aboriginal rights arise from the existence of distinctive aboriginal communities occupying 'the land as their forefathers had done for centuries. "1167

\section{SECTION 35(1)}

Lamer C.J.C. said that the purpose of s. 35(1) of the Constitution Act, 1982 is to reconcile prior aboriginal occupancy with Crown sovereignty. ${ }^{68}$ On the purpose of s. $35(1),{ }^{69}$ the dissenting judgments in Van der Peet did not diverge fundamentally from

Elsewhere they said that the term excludes features common to all societies, but does not require uniqueness, and focuses on the particular aboriginal community in question (Van der Peet (S.C.C.), supra note 1 at 553,559-61 (paras. 56,69,71)), but they did not indicate if the term comprehends some elements common to aboriginal societies.

For a more general common element, see the next paragraph.

See Part Il supra, referring to Van der Peet (S.C.C.), supra note 1 at 538-39 (para. 30).

Part VI infra.

Van der Peet (S.C.C.), supra note 1 at 540 (para. 33).

Ibid.

Ibid. at 539 (para. 31).

L'Heureux-Dube J. said that "s. 35(1) constitutionalizes the common law doctrine of aboriginal rights which recognizes aboriginal interests arising out of the historic occupation and use of ancestral lands by natives" (ibid. at 594 (para. 159)), and stressed that the provision must be given a broad interpretation. McLachlin J. did not reject the majority's description of s. 35(1), although she considered it incomplete. She said the section recognized a prior legal regime as well as prior occupation (ibid. at 628 (para. 230)). (Although McLachlin J. attributed this proposition to two passages she quoted from Sparrow, supra note 2 at 1105 , the connection is not clear. The second 
that of Lamer C.J.C. Here, as in its general discussion of the basis of aboriginal rights, ${ }^{70}$ the Court's emphasis was on occupancy - i.e., on land.

\section{V. "DISTINCTIVE PRACTICES" TEST}

Lamer C.J.C. stressed that the rights affirmed in s. 35(1) of the Constitution Act, 1982 are not just rights but "aboriginal." ${ }^{71} \mathrm{He}$ describes the purposes of the section as recognition of prior aboriginal occupation of land by distinctive aboriginal communities, and reconciliation of this fact with Crown sovereignty. He said "[t]he content of aboriginal rights must be directed at fulfilling both of these purposes." 72 Thus, he concluded, "the test for identifying the aboriginal rights recognized and affirmed by s. 35(1) must be directed at identifying the crucial elements of those pre-existing distinctive societies."73

Lamer C.J.C. then articulated a three-part test for identifying specific aboriginal rights:

(1) characterization of claim: determine the precise nature and purpose of the modern activity claimed to be an aboriginal right; ${ }^{74}$

(2) evaluation of traditional practice: "determine whether the activity claimed to be an aboriginal right is part of a practice, custom or tradition which was, prior to contact with Europeans, an integral part of the distinctive aboriginal society of the aboriginal people in question"175; and

(3) assessment of continuity between the traditional practice and the modern activity: determine whether there is sufficient continuity between the traditional practice and the modern activity claimed as an aboriginal right. ${ }^{76}$

To explore this test further, it is useful to look first at its relationship to the majority's description of the basis of aboriginal rights.

passage does support her other suggestion (ibid. at 628 (para. 230)) that settlement of aboriginal claims is part of the purpose of $s$. 35(1). However, the majority might argue that this goal is implied in their general notion of reconciliation and that its purposes are, in McLachlin J.'s words, "to preclude extinguishment and to provide a firm foundation for settlement of aboriginal claims" (ibid. at 629 (para. 232)).

Part II, supra. Note, however, L'Heureux-Dube J.'s position on content (supra notes 32 and 46). Van der Peet (S.C.C.), supra note 1 at 534 (para. 17) [emphasis in original].

Ibid. at 548 (para. 43).

Ibid. at 548 (para. 44).

Ibid. at 551-53, 563 (paras. 51-54, 76).

Lamer C.J.C. referring to this part of the Van der Peet test in Adams, supra note 3 at 123 (para. 37). See also Van der Peet, ibid. at 553-55 (paras. 55-59).

Van der Peet, ibid. at 556 (para. 63). In Adams, ibid., this part was combined with the traditional practice evaluation in the second stage of the test. 


\section{A MISSING LINK?}

As suggested above, a coherent test for identifying aboriginal rights today should relate to the basic nature of these rights. As Lamer C.J.C. said, although criteria should be applied in a modern context courts must take account of the "aboriginal" in "aboriginal rights." ${ }^{17}$ Because of the historic origin of aboriginal rights, modem claims must have some basis in the traditional situation of aboriginal peoples. But unless the law is to recognise all aboriginal traditional practices as aboriginal rights, courts must decide which aspects of the traditional situation should qualify as aboriginal rights.

The need to highlight some, rather than all, possible aspects of traditional life is underlined by s. 35(1) of the Constitution Act, 1982. Since 17 April 1982, a finding that a right is an aboriginal right is a finding that that right can prevail over all other legislation, federal or provincial. If, as Lamer C.J.C. said, s. 35(1) is intended not only to protect the fact of prior aboriginal occupation but to reconcile it with Crown sovereignty, the scope of paramount aboriginal rights cannot be co-extensive with the scope of traditional aboriginal life. Non-designation as a s. 35(1) aboriginal right does not, of course, limit other special rights to which Canadian aboriginal peoples may be entitled. ${ }^{78}$

Lamer C.J.C. concluded that the test for identifying aboriginal rights should look for the "crucial elements" of traditional aboriginal societies. As we have seen, the majority found that the crucial elements of these societies are traditional occupation of land and participation in distinct societies. ${ }^{79}$ If the test for identifying aboriginal rights is to

Van der Peet, ibid. at 534 (para. 17).

7 In situations not meeting the requirements of s. 35(1) aboriginal rights, there may be s. 35(1) treaty rights, including land claims agreement rights; legislative rights (i.e., under the Indian Act, R.S.C. 1985, c. I-5); and native customary law rights (see, for example, N. Zlotkin, "Judicial Recognition of Aboriginal Customary Law in Canada: Selected Marriage and Adoption Cases" [1984] 4 C.N.L.R. 1). There is also a possibility of invoking international law rights, depending on their status in the international community and on whether they are incorporated into and consistent with Canadian domestic law (see L.C. Green, International Law: A Canadian Perspective, $2 \mathrm{~d}$ ed. (Toronto: Carswell, 1988) at 76-90). For possible examples of these, see International Covenant on Civil and Political Rights, 16 December 1966, Can. T.S. 1976 No. 47, art. 1, para. 1 (selfdetermination and minority rights, respectively); International Covenant on Economic, Social and Cultural Rights, 16 December 1966, Can. T.S. 1976 No. 46, art. 1, para. 1 (self-determination); Declaration on Principles of International Law Concerning Friendly Relations and Co-operation among States in Accordance with the Charter of the United Nations, UN GA Res. 2625 (XXV), UN GAOR, 25th Sess., 1883d Plen. Mtg., Supp. No. 28 at 121, UN Doc. A/8018 (1970), arts. 1 and 2; and the Draft Declaration on the Rights of Indigenous Peoples, reproduced in [1994] 1 C.N.L.R. 48. See further: M.J. Bryant, "Aboriginal Self-Determination: The Status of Canadian Aboriginal Peoples at International Law" (1992) 56 Sask. L. Rev. 267; B. Berg, "Introduction to Aboriginal Self-Government in International Law: An Overview" (1992) 56 Sask. L. Rev. 367; and S.J. Anaya, Indigenous Peoples in International Law (New York: Oxford U. Press, 1996), c. 2-3, and at 109-12. 
reflect their basic nature, one would expect that this test would look for some link to land as well as - or as a part of - a distinctive society. ${ }^{80}$

Lamer C.J.C. said that in considering whether an aboriginal rights claim can succeed, courts must look at the claimant's relationship to land as well as at the practices, traditions and customs ${ }^{81}$ which are integral to the claimant's distinctive culture. ${ }^{82}$ On the other hand, Lamer C.J.C. failed to make this relationship an explicit part of the distinctive practices test. At some points he seemed to suggest that this test is sufficient on its own to prove aboriginal rights. ${ }^{83}$ Moreover, although the Chief Justice's discussion of the basis of aboriginal rights implied that land is part of the distinctiveness of aboriginal cultures, ${ }^{84}$ the discussion of the distinctive practices test did not. Lamer C.J.C.'s main concern here appears to have been less to distinguish aboriginal cultures from those of other groups, than to characterize and distinguish aboriginal cultures on an individual basis. ${ }^{85}$

Starting with their general "land and societies" approach ${ }^{86}$ to the basis of aboriginal rights, then, the majority in Van der Peet seem to have ended up with a "societies" approach $^{87}$ to identifying aboriginal rights in specific situations. What happened to the link to land? Had it no real importance in the first place? Was it implicit in the distinctive practices identification test? As will be seen later, these questions involve more than just theoretical consistency.

The test need not be narrow. The historical notion of land and the complexity of traditional aboriginal life both militate against restricting this link to land to a literal sense. Constitutionally, "land" can include not only use of the surface but mines (e.g., B.C. (A.-G.) v. Canada (A.-G.) (1899), 14 A.C. 295 (J.C.P.C.)); minerals (ibid.); renewable resources such as timber (e.g., St. Catherine's Milling, supra note 61); and of adjoining waters and water resources such as fish (e.g., R. v. Robertson (1882), 6 S.C.R. 52; Re Provincial Fisheries (1895), 26 S.C.R. 444). Thus traditional land use, not a narrow definition of land, can form the basis for the content of aboriginal rights. Moreover, as many traditional aboriginal societies were highly mobile, not all aboriginal activities need be located on land which is subject to aboriginal title (see Adams, supra note 3 at 118 (para. 27)). As well, the Supreme Court has said in Adams that aboriginal rights need not involve a traditional connection to land that would be sufficient to establish a claim to aboriginal title (ibid. at 117-18 (para. 26)). Nor need the relationship to land prevent activities originally tied directly to land from evolving into modem forms. On the other hand, if historic traditional occupation and use is to have any significance at all, it should mean more than the nominal fact that traditional aboriginal activities took place on land or adjacent water. For convenience, in the remainder of this comment the words "practice" and "practices" will refer to "practice, tradition, and custom" and "practices, traditions or customs," respectively.

Van der Peet (S.C.C.), supra note 1 at 562 (para. 74).

For example, ibid. at 556, 560 (paras. 63, 71).

Ibid. at 538-39 (para. 30) and supra, Part I, second last paragraph.

See, e.g., his quotation (at 545-46 (para. 40)) from Mabo v. Queensland [No. 2], supra note 60 at 58, and his statement that "[a]boriginal rights are not general and universal; their scope and content must be determined on a case by case basis.... The existence of the right will be specific to each aboriginal community" (at 559 (para. 69)).

Part II, supra.

I.e., the distinctive practices test. 


\section{JUSTICE MCLACHLIN'S CRITICISMS}

In her dissenting opinion in Van der Peet, McLachlin J. charged that the distinctive practices test on its own is "overinclusive, indeterminate, and ultimately categorical." For example, she said that under dictionary definitions of "integral,"

anything which can be said to be part of the aboriginal culture would qualify as an aboriginal right protected by the Constitution Act, 1982. This would confer constitutional protection on a multitude of activities, ranging from the trivial to the vital. ${ }^{28}$

The terms "integral" and "distinctive" did seem subjective, and capable of assessment by different and contradictory criteria. A conclusion based on quantity may conflict with one based on frequency, or one based on emphasis in traditional beliefs. The elasticity of these terms was illustrated by the very different ways they were applied in Van der Peet itself. ${ }^{89}$

The initial characterization process was especially complex ${ }^{90}$ and open-ended. At the Court of Appeal and Supreme Court levels, Van der Peet's claim was characterized by seven different judges in five different ways. ${ }^{91}$ Yet the characterization of an

Van der Peet (S.C.C.), supra note 1 at 638 (para. 256). McLachlin J. added that the majority's notions of distinctiveness and specificity were too imprecise to resolve this "problem of overbreadth" (ibid. at 639 (para. 257)).

For example, the majority said the distinctive practices test requires the court to ask if a practice was sufficiently important to the defining features of a particular society. Yet L'Heureux-Dube J. was able to apply the same test and conclude that the relevant question is whether a practice was sufficiently important "to the culture and social organization" of the aboriginal society (ibid. at 617 (para. 206), and see also ibid. at 593, 595 (paras. 157, 162)). Although McLachlin J. agreed with L'Heureux-Dube J.'s interpretation of the test (ibid. at 638 (para. 255)), she then dismissed the test itself as inadequate.

The characterization process was complicated by the majority's willingness to consider factors other than the appearance of the activity that is the subject of the claim (see ibid. at 552 (para. 53)).

For example, Macfarlane and Taggart JJ.A. characterized the claim as a right "to sell fish ... on a commercial basis" (Van der Peet (B.C.C.A.), supra note 1 at 469 (para. 30)). Wallace J.A. described it as a right "to sell fish" (ibid. at 477 (para. 68)). Lambert J.A. characterized it, inter alia, as a right "to catch and ... sell sufficient salmon [to provide those fishing and their dependent families] with a moderate livelihood" (ibid. at 499 (para. 150)). In the Supreme Court, Lamer C.J.C. characterized the claim a right "to exchange fish for money or other goods" (Van der Peet (S.C.C.), supra note 1 at 563 (para. 77)). L'Heureux-Dube J. characterized it as a right "to sell, trade and barter fish for livelihood, support and sustenance purposes" (ibid. at 572, 608-609, 612, 617, 624 (paras. 96, 191, 192, 199, 206, 221)). McLachlin J. called the claim a right "to fish for sustenance" (ibid. at 626-27,648,656, 670 (paras. 227, 275, 294, 322)), although her later descriptions of the content of the right were similar to that of Lambert J.A. There were also sharp differences as to what qualifies as "commercial." For the majority a commercial transaction is a large-scale exchange for money or other goods (Van der Peet, (S.C.C.), ibid. at 563 (para. 77); and see N.T.C. Smokehouse, supra note 1 at 686-87 (paras. 17 and 18)). L'Heureux-Dubé J. associated "purely" commercial transactions with the notions of profit (Van der Peet (S.C.C.), supra note 1 at $607,609,610,623$ (paras. 189, 192, 194, 218)). For L'Heureux-Dubé J., the purposes of aboriginal activities "should be viewed on a spectrum, with aboriginal activities undertaken solely for food, at one extreme, those directed to obtaining purely commercial profit, at the other extreme, and activities relating to livelihood, support and sustenance, at the centre" (ibid. at 609 
aboriginal rights claim defines the assessment of the traditional activity. The wider the characterization, the more likely the claimant can prove a traditional practice, and vice versa. ${ }^{92}$ In a very real way, characterization helps determine results. ${ }^{93}$ McLachlin $\mathrm{J}$. said the Chief Justice's emphasis on particularity "enabl[es] him to find no aboriginal right where a different analysis might find one." ${ }^{94}$ The Chief Justice might have made a similar observation about the opposite effect of the dissenting judgments. ${ }^{95}$

This uncertainty was exacerbated by conflicting views on the appropriate period in which to assess traditional practices. The majority focused on the pre-contact period. By doing this, they deprived themselves of most of the written records and first-hand oral experience normally required in courts. Lacking these tools, they had to come to a significant constitutional conclusion about a society far removed from them in culture and in time. L'Heureux-Dubé J.'s alternative suggestion that courts consider any twenty to fifty year time period would have traded this evidentiary uncertainty for chronological uncertainty. ${ }^{96}$ As well, it could have minimized the element of prior occupancy at the heart of aboriginal rights. ${ }^{97}$

The notion of continuity also posed problems of indeterminancy, problems that are closely related to the issue of characterization. The broader the characterization, the more readily courts can find continuity. For example, the majority's right to "exchange

(para. 192)). For McLachlin J. any sale is commercial: (ibid. at 630-31 (paras. 236-37)).

For example, if the courts had decided to characterize all fishery uses other than food or ceremonial uses as "commercial" and requiring large-scale market transactions, then few traditional fishing practices would likely qualify as aboriginal rights. Conversely, if courts characterized commercial and other uses as one aspect of a blanket right to benefit from fishing, courts would ensure that few practices would not qualify.

In his decision, Lamer C.J.C. stressed the specific purpose of the claimed activity. By linking this purpose (in her words, the right to "sell, trade and barter" to the wider objectives of "livelihood, support and sustenance" (ibid. at 572 (para. 96)), L'Heureux-Dubé J. would have broadened this approach. By focusing only on sustenance, McLachlin J. would have broadened it further. Ibid. at 632 (para. 241). See also ibid. at 631 (para. 239).

95 McLachlin J.'s own dissenting reasons illustrate the power of characterization. McLachlin J. considered Van der Peet's own claim to be a right to fish commercially (ibid. at 630-31 (paras. 236-37)). But McLachlin J. regarded this as only the starting point to characterizing the traditional practice itself. At its base, she said, "the right is not the right to trade, but the right to continue to use the resource in the traditional way to provide for the traditional needs, albeit in their modem form" (ibid. at 649 (para. 278); see also 626-27, 646, 648, 668-69 (paras. 227, 272, 275, 318)). For this case, McLachlin J. said the court should look to see if there was a corresponding traditional use of the fishery resource (ibid. at 648-49 (paras. 276-78)). If so, the claimant is entitled to the modern economic equivalent of the traditional use. Although McLachlin J.'s approach places quantitative limits on the modern enjoyment of aboriginal rights, it would significantly expand the scope of traditional activities that could qualify as aboriginal rights in the first place. L'Heureux-Dube J. provided no guidance as to which twenty to fifty year period to select. As Lamer C.J.C. said (Van der Peet (S.C.C.), supra note 1 at 555 (para. 60)), "[b]ecause it is the fact that distinctive aboriginal societies lived on the land prior to the arrival of Europeans that underlies the aboriginal rights protected by s. 35(1), it is to that pre-contact period that the courts must look in identifying aboriginal rights." McLachlin J. agreed with the majority that the relevant period is the pre-contact period, but suggested that courts should not become overly concerned to establish a precise moment of first European contact (ibid. at 634-35 (paras. 247-48)). 
fish for money or other goods"98 is more vulnerable to continuity breaks than McLachlin J.'s wider right to "[draw] a moderate livelihood from the fishery." 99 The decision also raised questions as to when continuity is broken by interrupted use or by extraneous influences. Although the majority said interruptions in an activity do not necessarily affect its status as an aboriginal right, they did not indicate when an interruption becomes a final break. The majority said that European influence cannot break continuity unless it is the "sole" reason for a practice, ${ }^{100}$ yet they considered it significant that the exchange of salmon between the Hudson's Bay Company and the Sto:lo occurred "primarily" because of European influences. ${ }^{101}$

McLachlin J.'s response to the problems of indeterminacy and categorical results was to find a link between aboriginal rights and land on one hand and "economic equivalency" on the other. Under her economic equivalency approach, a particular aboriginal people have the right "to take from the resource the modern equivalent of what by aboriginal law and custom it historically took." ${ }^{102}$ Hence if the claimants can show that they have traditionally derived "a moderate livelihood" from a natural resource, they may be able to establish an aboriginal right to a moderate livelihood from that resource today, by modern means. ${ }^{103}$ McLachlin J. claimed that this approach provides some of the internal limits that the majority's version of the distinctive practices test lacks. ${ }^{104}$ As a result, it reduces indeterminancy, prevents categorical results, and avoids the need to add to the justification component of the Sparrow test for S. 35(1). ${ }^{105}$

However, economic equivalency generates its own indeterminacy. To assess a modern economic equivalent to the value of an activity carried on as many as hundreds of years ago is a daunting task. ${ }^{106}$ In the United States, where the moderate livelihood criterion has been criticized as uncertain, the best known use of the test has at least a fixed upper limit.

In Gladstone, a majority of the Supreme Court suggested that the place for assessing possible restrictions on the enjoyment of aboriginal rights in relation to other needs is

$98 \quad$ Ibid. at 563 (para. 77).

$99 \quad$ Ibid. at 649 (para. 279).

$100 \quad$ Ibid. at 561-62 (para. 73).

$101 \quad$ lbid. at 570 (para. 89).

102 Jbid. at 650 (para. 279). The approach was first suggested in a Canadian context by Lambert J.A., dissenting in Van der Peet (B.C.C.A.), supra note 1.

to3 Van der Peet (S.C.C.), ibid.

iot Ibid. at 649-50, 658-59 (paras. 279, 302).

$\cos$

As the majority of the Court did in Gladstone, supra note 1.

so6

What, it might be asked, is a "moderate livelihood"? An amount equivalent to the minimum wage? Is it to be determined on a per capita basis? What happens if some members of the group are earning far more than a moderate livelihood, while others are barely surviving? Does a moderate livelihood for one group require the same amount as a moderate livelihood for another? Will the standard shift with the cost of living? With the inflation rate? Will courts be required to maintain an ongoing watch on individual situations to ensure that a moderate livelihood earned today will still be earned tomorrow? 
the justification branch of the infringement-justification test in Sparrow. ${ }^{107}$ Despite McLachlin J.'s criticisms of this approach, ${ }^{108}$ it does consider the relative priority to be accorded to aboriginal rights in the forum in which they can be weighed explicitly against other interests, rather than in a relative vacuum.

\section{A RETURN TO LAND?}

There is no simple answer to the indeterminancy of the distinctive practices test. Courts cannot respect the special traditional origins of aboriginal rights without producing an interest that is difficult to identify. On the other hand, they can do more than to say, as the majority said, that aboriginal rights derive from practices important to the distinctive features of a particular traditional society. In this regard, McLachlin J.'s other main suggestion might provide some help: what might be needed is a meaningful relationship with land or its resources.

What kind of link to land is desirable? There are a number of possible alternatives:

(1) Aboriginal rights are linked to land in the sense that they must be based on proof of aboriginal title. This alternative was rejected explicitly in the Supreme Court's recent decision in Adams. ${ }^{109}$

(2) Aboriginal rights need be linked to land only in the nominal sense that they "take place" on land. This approach would render the link to land meaningless, as it would include virtually all forms of traditional activity. It would undermine the stress on prior occupancy in the majority's discussion of the basis of aboriginal rights. It would be at odds with most existing case law. It would leave the distinctive practices test without form or content.

Gladstone, supra note 1 at $762-80$ (paras. 54-84), especially 766-68 (paras. 62-63) (aboriginal rights that lack internal limitations should be given an allocation priority which is less than exclusivity) and at 775 (para. 75) (not only conservation, but goals such as regional and economic faimess and needs of third parties, are relevant to resource allocation).

Van der Peet (S.C.C.), supra note 1 at 658-67 (paras. 302-15). McLachlin J. argued, inter alia, that Sparrow and the Crown's fiduciary duty to aboriginal peoples prohibits courts from justifying infringements of aboriginal rights by reference to non-aboriginal interests (at 659-62 (paras. 303307)); that the Gladstone approach treats s. 35(1) rights as if they were subject to the s. 1 constraint in the Charter (at 662-63 (para. 308)); that the approach is indeterminate (at 663-64 (para. 309)); and that courts cannot constitutionally dilute the content of s. 35(1) rights (at 667 (para. 315)). On the other hand: (i) the court did not say in Sparrow that conservation and avoiding harm are the only possible justification factors, and even these factors contemplate interests of nonrights holders; (ii) the Sparrow application of the Crown's fiduciary duty to aboriginal peoples is sui generis, and does not necessarily impose obligations identical to those of private fiduciaries (see D.W. Elliott, "Aboriginal Peoples in Canada and the United States and the Scope of the Special Fiduciary Relationship" (1996) 24 Man. L.J. 137 at 145-47 and at note 212); (iii) although s. 35(1) rights lack the restraints in $\mathrm{s}$. 1 of the Charter they also lack its explicit guarantee; (iv) allocating priorities as between aboriginal interests and other concerns will be an indeterminate exercise wherever it is carried out; and $(v)$ courts cannot be said to act unconstitutionally by "modifying" s. 35(1) rights when it is they who have the responsibility of interpreting these rights in the first place. 
(3) Aboriginal rights are linked to land in the sense that they are site-specific, and tied to certain areas of land only. Although this approach would describe some aboriginal activities, it is unduly restrictive. It might exclude, for example, the sale by Van der Peet, since that sale took place at her home and not where the salmon were caught.

(4) Aboriginal rights are linked to land in the sense that they involve some form of occupancy of land or use of land or its adjoining resources. This approach would avoid any necessary tie to aboriginal title, would accommodate mobility of use, would permit a broad range of traditional activities to be classified as aboriginal rights, would be consistent with the Royal Proclamation and the dominant case law, would reflect the discussion of the basis of aboriginal rights in Van der Peet itself, and would give the Van der Peet identification test some of the clarity it badly needs.

The Court could implement the fourth alternative by clarifying that the reference to practices, traditions and customs which are integral to the distinctive culture of an aboriginal society, is characteristically a reference to practices, traditions and customs that involve some use of land or its adjoining or related natural resources. This approach would not have resolved the controversy in Van der Peet itself, since the Sto:lo's traditional activity was clearly connected with land and resources. On the other hand, it could help provide courts with a general core area within which claims that meet reasonable evidentiary requirements would normally qualify for judicial protection. ${ }^{110}$ Conversely, s. $35(1)$ aboriginal rights protection would not normally extend to activities outside the core area."' The link would not prevent non-land activities from achieving legal recognition outside s. 35(1) if they met the criteria for customary rights, nor would it prevent them from being defined and enforced in statutes, agreements, and special constitutional enactments.

By moving in this direction, then, the Supreme Court could clarify the Van der Peet identification test, reconcile it with their own discussion of basic principles, and give some general shape to the basic rights it guaranteed in Sparrow: not a bad return on fifty dollars of fish.

Subject to the infringement and justification tests in Sparrow, supra note 2 and Gladstone, supra note 1.

i11 For example, adoption, marriage, penal and gambling customs, and general regulatory régimes might fall in this category unless a special tie to land could be shown. 